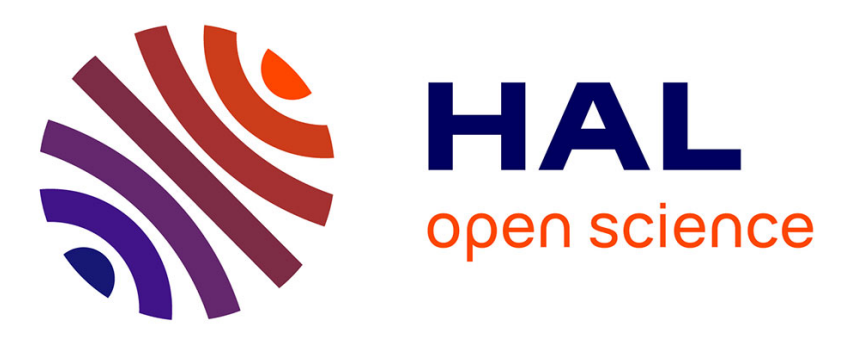

\title{
Influence of land use on carbon sequestration and erosion in Mexico, a review
}

J.D. Etchevers, C. Prat, C. Balbontín, M. Bravo, M. Martínez

\section{To cite this version:}

J.D. Etchevers, C. Prat, C. Balbontín, M. Bravo, M. Martínez. Influence of land use on carbon sequestration and erosion in Mexico, a review. Agronomy for Sustainable Development, 2006, 26 (1), pp.21-28. hal-00886314

\section{HAL Id: hal-00886314 https://hal.science/hal-00886314}

Submitted on 1 Jan 2006

HAL is a multi-disciplinary open access archive for the deposit and dissemination of scientific research documents, whether they are published or not. The documents may come from teaching and research institutions in France or abroad, or from public or private research centers.
L'archive ouverte pluridisciplinaire HAL, est destinée au dépôt et à la diffusion de documents scientifiques de niveau recherche, publiés ou non, émanant des établissements d'enseignement et de recherche français ou étrangers, des laboratoires publics ou privés. 


\title{
Influence of land use on carbon sequestration and erosion in Mexico, a review ${ }^{1}$
}

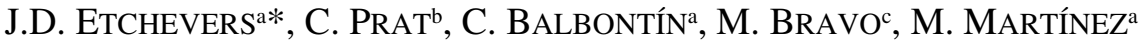 \\ ${ }^{\text {a }}$ Colegio de Postgraduados, IRENAT, 56230 Montecillo, Mexico \\ ${ }^{\mathrm{b}}$ IRD, MTD, 500 rue J.F. Breton, 34093 Montpellier Cedex 05, France \\ ${ }^{c}$ CENAPROS-INIFAP, AP 7-116, 58260 Morelia, Michoacán, Mexico
}

(Accepted 26 January 2005)

\begin{abstract}
To reduce the impact of human activities on soil erosion and to increase $\mathrm{C}$ sequestration, a series of alternative systems have been tested in recent years on hillside agriculture in Mexico. Among other systems, conservation tillage and intercropping staple crops and fruit trees have been successful. Since accumulation of $\mathrm{C}$ occurs in those systems, it is concluded that the rate of $\mathrm{C}$ entrance to the soil-plant exceeds the rate of $\mathrm{C}$ exit. The identification and understanding of the structure of such a system, its components, and the role of each one of these components, is fundamental to intervening in order to enhance reduction of soil erosion and C sequestration. A summary of experiments on this subject collected in Mexico is presented in the present paper. The most striking findings are: hillside agricultural systems can store, and probably sequester, as much $\mathrm{C}$ as secondary native forestry systems, and soil erosion and $\mathrm{C}$ losses are small when proper management systems are applied.
\end{abstract}

\section{INTRODUCTION}

Mexico's population has increased from 25 to approximately 100 million inhabitants in half a century, but the country's surface is the same, nearly 200 million hectares. Only $11 \%$ of the total land is apt for farming, and only $16 \%$ of this is prime arable land suitable for high-input agriculture. Six million hectares are irrigated, but water is one of the most serious limiting factors for present and future agriculture. The rest of the land is mostly either located on steep-slope terrain or in marginal semiarid conditions inhabited by just over 3 millions farmers (INEGI, 1998; Tiscareño et al., 2000). The shortage of farmland has resulted in increasing aggression to native forest and in a constant increment of steep slopes being cultivated. As a consequence, temperate and tropical forests have experienced a reduction of 30 and $75 \%$ since 1960, respectively. According to the World Resources Institute (WRI, 2002), Mexico ranks among countries with the highest annual rates of native forest losses.

Agriculture is practiced in the four ecological macro-regions recognized in Mexico: an arid and semiarid region $(<500 \mathrm{~mm}$ annual rainfall) covering approximately one-half of the national territory, a dry tropical region (900-1200 mm, with seasonal rainfall) that occupies one-fourth of the surface and the remaining areas (13 and $8 \%$ ) are covered by the temperate hilly areas $(600-900 \mathrm{~mm})$ and the humid tropics (>1 $200 \mathrm{~mm})$, respectively (Claverán, 2000). Accelerated soil erosion affects $80 \%$ of Mexico's land (Maass and García-Oliva, 1990) and nearly 535 million tons of soil is lost annually (SEMARNAP,
1997). According to Maas and García-Oliva (1990), more soil has been lost during the last 40 years than in the past four centuries. Concurrent surface and gully erosion from deforestation and inappropriate cultivation of non-irrigated land have been identified on 65 to $85 \%$ of the land (Bocco and García-Oliva, 1992). The erosion is aggravated by the topographic and weather conditions of the country, which presents extreme variations in altitude (sea level to more than $5000 \mathrm{~m}$ ) and climate conditions ranging from desert to tropical humid forest ( $<200 \mathrm{~mm}$ to $>2000 \mathrm{~mm}$ rainfall).

Land degradation and erosion are common features in most of the agricultural land in Mexico, particularly on hillside agriculture along the sierras that criss-cross the country, but mainly in the southern part where rainfall is abundant. The main types of land degradation and percentage of land affected are presented in Table I (CONAZA, 1994). Biological degradation is also caused by loss of the topsoil and excessive cropping. The former ranges from less than $10 \mathrm{Mg} \mathrm{ha}^{-1}$ up to $200 \mathrm{Mg} \mathrm{ha}^{-1}$ (CONAZA, 1994) and seriously reduces productivity. Water erosion is closely associated with slopes higher than $10 \%$ and management practices which tend to leave the soil without protection when the rainy season starts. Eolic erosion is more common under arid and semiarid conditions. Losses of approximately $140 \mathrm{Mg} \mathrm{ha}^{-1}$ of soil have been reported for eolic erosion (Amante, 1989; Osuna, 1991). The average soil loss in the country is approximately $2.8 \mathrm{Mg} \mathrm{ha}^{-1}$ (Figueroa and Ventura, 1990). Biological erosion is the second largest degradation process after water erosion in Mexico and it represents the rate of organic matter mineralization. Approximately $80 \%$ of the

\footnotetext{
${ }^{1}$ This article has been presented at the Colloquium of Montpellier entiled "Land use, Erosion \& Carbon Sequestration" organized by the "Réseau Érosion francophone" and the Lab. MOST of IRD and CIRAD (information: Dr. Eric Roose, Eric.Roose@ ird.mpl.fr).

* Corresponding author: jetchev@ colpos.mx
} 
Table I. Land degradation in the Mexican territory (CONAZA, 1994).

\begin{tabular}{lc}
\hline Type of land degradation & Fraction of the territory affected \\
& $\%$ \\
\hline Water erosion & 85 \\
Wind erosion & 60 \\
Leach bases & 15 \\
Physical degradation & 20 \\
Biological degradation & 80 \\
Salinity & 20 \\
Sodification & 15 \\
\hline
\end{tabular}

territory is affected by biological degradation. Organic matter degradation is more likely to occur in areas closer to coastlines and less likely in the semiarid and arid zones. Both soil degradation processes are closely related to $C$ sequestration capacity. Soil conservation practices as well as agronomic practices have been introduced to reduce soil degradation. These practices help to retain the soil $\mathrm{C}$ in their storages and may contribute to increasing the rate of $\mathrm{C}$ sequestration.

\section{SOIL CARBON AND CARBON SEQUESTRATION}

Appropriate tillage techniques were viewed in the past as soil erosion mitigation tools. However, today they are also viewed as a means to increase soil $\mathrm{C}$ sequestration. Soil organic $\mathrm{C}$ (SOC) plays a key role in the global $\mathrm{C}$ cycle and acts as a sink for atmospheric $\mathrm{CO}_{2}$. This pool can be managed to increase the terrestrial SOC pool However, the potential of the ecoregions to sequester $\mathrm{C}$ varies with soil type and depth, climate, land use and management. Soil tillage methods without soil inversion, like no-tillage systems, help to increase the SOC pool (Lal, 1984, 1989). Conversely, soil management practices leading to soil inversion and disturbance may result in a decrease in the SOC content. The SOC is an important contributor to soil quality. Because of these reasons, $\mathrm{SOC}$ has received increased attention as a possible method to store $\mathrm{C}$ and reduce future increases in atmospheric $\mathrm{CO}_{2}$ concentration (Kern and Johnson, 1993). However, limited information has been published in Mexico on the effect of conservation tillage on soil C (Báez, 2001; Etchevers, 2002; Salinas et al., 2001; Sandoval, 1997; Velásquez and Pérez, 2001). A brief summary of some relevant case studies recently published is presented.

\subsection{Soil carbon and soil management. Mega-environment 2 case study (Sandoval, 1997)}

Table II shows the effect of conventional, zero tillage and previous crop residues management on soil organic matter (SOM), SOC, soluble-C, Kjeldahl $\mathrm{N}$ and $\mathrm{C} / \mathrm{N}$ after 5 years in a Phaeozem representative on Mega-Environment 2 (Highland Valleys of Mexico, Kenya, Ethiopia) (Sandoval, 1997; Etchevers, 2002). The data given are the average value of eight different rotations including maize, wheat and vicia. Zero tillage influenced SOC, soluble-C and $\mathrm{N}$, in the first $40 \mathrm{~cm}$ of the profile. The largest effects of tillage systems were observed on SOC and soluble-C in the 0 to $5 \mathrm{~cm}$ depth increment. Zero tillage treatments accumulated more SOC than conventional tillage in the superior soil layers after 5 years, but more SOC was accumulated in the 0 to $20 \mathrm{~cm}$ depth increment of conventional

Table II. Effect of soil tillage and residue management on soil organic matter (OM), total soil organic C (C), soluble-C (Csol), Kjeldahl-N (NKj) and $\mathrm{C} / \mathrm{N}$ after 5 years of treatment (Sandoval, 1997).

\begin{tabular}{|c|c|c|c|c|c|}
\hline \multicolumn{3}{|c|}{ Main treatments } & \multicolumn{3}{|c|}{ Indicator $\dagger$} \\
\hline & $\mathrm{OM}$ & $\mathrm{C}$ & Csol & Nkj & $\mathrm{C} / \mathrm{N}$ \\
\hline & $\%$ & $\%$ & Abs & $\%$ & \\
\hline & \multicolumn{5}{|c|}{$0-5 \mathrm{~cm}$ depth } \\
\hline Zero tillage & $2.3 \mathrm{a}$ & $1.32 \mathrm{a}$ & $0.309 \mathrm{a}$ & $1.12 \mathrm{a}$ & $11 \mathrm{a}$ \\
\hline Conventional tillage & $1.8 \mathrm{~b}$ & $1.05 \mathrm{~b}$ & $0.250 \mathrm{~b}$ & $0.10 \mathrm{~b}$ & $11 \mathrm{a}$ \\
\hline With residues & $2.1 \mathrm{a}$ & $1.23 \mathrm{a}$ & $0.311 \mathrm{a}$ & $0.12 \mathrm{a}$ & $11 \mathrm{a}$ \\
\hline \multirow[t]{2}{*}{ Without residues } & $2.0 \mathrm{a}$ & $1.15 b$ & $0.256 \mathrm{~b}$ & $0.11 \mathrm{a}$ & $11 \mathrm{a}$ \\
\hline & \multicolumn{5}{|c|}{$5-10 \mathrm{~cm}$ depth } \\
\hline Zero tillage & $1.9 \mathrm{a}$ & $1.09 \mathrm{a}$ & $0.233 \mathrm{a}$ & $0.10 \mathrm{a}$ & $0.11 \mathrm{a}$ \\
\hline Conventional tillage & $1.8 \mathrm{a}$ & $1.07 \mathrm{a}$ & $0.247 \mathrm{a}$ & $0.10 \mathrm{a}$ & $0.11 \mathrm{a}$ \\
\hline With residues & $2.0 \mathrm{a}$ & $1.14 \mathrm{a}$ & $0.265 \mathrm{a}$ & $0.10 \mathrm{a}$ & $0.11 \mathrm{a}$ \\
\hline \multirow[t]{2}{*}{ Without residues } & $1.8 \mathrm{a}$ & $1.04 \mathrm{a}$ & $0.222 b$ & $0.10 \mathrm{a}$ & $0.11 \mathrm{a}$ \\
\hline & \multicolumn{5}{|c|}{ 10-20 cm depth } \\
\hline Zero tillage & $1.6 \mathrm{~b}$ & $0.95 b$ & $0.218 \mathrm{a}$ & $0.09 b$ & $11 \mathrm{a}$ \\
\hline Conventional tillage & $1.9 \mathrm{a}$ & $1.09 \mathrm{a}$ & $0.226 \mathrm{a}$ & $0.10 \mathrm{a}$ & $11 \mathrm{a}$ \\
\hline With residues & $1.8 \mathrm{a}$ & $1.06 \mathrm{a}$ & $0.234 \mathrm{a}$ & $0.10 \mathrm{a}$ & $11 \mathrm{a}$ \\
\hline Without residues & $1.7 \mathrm{a}$ & $1.00 \mathrm{a}$ & $0.213 \mathrm{a}$ & $0.09 b$ & $11 \mathrm{a}$ \\
\hline
\end{tabular}

$\dagger$ Different letters after the number indicates significant differences. Comparison must be made between zero and conventional tillage and between with and without residues. 
Table III. Organic C in the above-ground, root and soil $(0-105 \mathrm{~cm})$ components in land-use systems prevailing in three regions of Northern Sierra, Oaxaca, Mexico (Etchevers, 2002).

\begin{tabular}{|c|c|c|c|c|c|c|c|c|c|c|c|}
\hline \multirow{4}{*}{ Component } & \multicolumn{3}{|c|}{$\begin{array}{l}\text { Natural } \\
\text { systems }\end{array}$} & \multicolumn{8}{|c|}{ Agricultural systems } \\
\hline & \multicolumn{11}{|c|}{$\mathrm{Mg} \mathrm{ha}^{-1}$} \\
\hline & \multicolumn{11}{|c|}{ Mazateca } \\
\hline & LF & AF15 & AF10 & $\mathrm{CA}$ & $\mathrm{PA}$ & $\mathrm{Plw}^{1}$ & $\mathrm{Plw}^{2}$ & $\mathrm{CT}^{1}$ & $\mathrm{CT}^{2}$ & $\mathrm{TT}^{1}$ & $\mathrm{TT}^{2}$ \\
\hline Aerial part & 99.5 & 46.3 & 31.0 & 34.5 & 5.4 & 6.1 & 3.5 & 6.1 & 3.5 & 3.2 & 1.8 \\
\hline Root & 3.3 & 2.3 & 4.1 & 4.8 & 1.4 & 1.5 & 2.9 & 2.3 & 4.3 & 2.0 & 5.5 \\
\hline Soil & 152 & 156 & 240 & 148 & 174 & 158 & 128 & 266 & 273 & 235 & 195 \\
\hline \multirow[t]{3}{*}{ Total } & 255 & 205 & 275 & 187 & 181 & 166 & 135 & 274 & 281 & 240 & 202 \\
\hline & \multicolumn{11}{|c|}{ Cuicateca } \\
\hline & $\mathrm{QF}$ & & & PR & & Plw & $\mathrm{Plw}^{2}$ & $\mathrm{CT}^{2}$ & $\mathrm{CT}^{2}$ & $\mathrm{TT}^{2}$ & $\mathrm{TT}^{2}$ \\
\hline Aerial part & 37.6 & & & 2.2 & & 4.3 & 3.4 & 4.2 & 3.8 & 3.3 & 2.7 \\
\hline Root & 14.4 & & & 6.1 & & 0.7 & 1.0 & 1.9 & 1.2 & 0.6 & 0.6 \\
\hline Soil & 45 & & & 91 & & 63 & 113 & 66 & 49 & 57 & 65 \\
\hline \multirow[t]{3}{*}{ Total } & 97 & & & 99 & & 68 & 117 & 72 & 54 & 61 & 68 \\
\hline & \multicolumn{11}{|c|}{ Mixe } \\
\hline & $\mathrm{AC} 10$ & $\mathrm{AC} 7$ & $\mathrm{AC} 2$ & $\mathrm{CA}$ & & $\mathrm{Clw}$ & & $\mathrm{CT}$ & $\mathrm{TT}$ & & \\
\hline Aerial part & 25.0 & 24.1 & 9.9 & 11.2 & & 5.6 & & 3.1 & 4.8 & & \\
\hline Root & 7.8 & 5.1 & 3.8 & 4.0 & & 1.9 & & 2.8 & 2.9 & & \\
\hline Soil & 120 & 169 & 119 & 160 & & 266 & & 278 & 298 & & \\
\hline Total & 153 & 199 & 133 & 175 & & 273 & & 284 & 306 & & \\
\hline
\end{tabular}

$\mathrm{LF}=$ Liquidambar forest $\mathrm{AF} 10$ and $\mathrm{AF} 15=$ Alnus forest of 10 and 15 years old PA $=$ Pasture, $\mathrm{Plw}=$ Peach living walls: $\mathrm{CT}$ and TT $=\mathrm{Conservation}$ Tillage and Traditional Tillage; $\mathrm{QF}=$ Quercus Forest; $\mathrm{AC} 2, \mathrm{AC} 7, \mathrm{AC} 10=$ Acahuales of 2, 7 and 10 years old; $\mathrm{CA}=\mathrm{Coffee} ; \mathrm{Clw}=\mathrm{Coffee} \mathrm{living} \mathrm{walls;}$ $1>30 ;{ }^{2}<30=$ slope percentage.

tillage than zero tillage. This was attributed to the effect of surface soil being plowed under. Surface soil contains more root and plant residues than the underlying soil. When this is plowed under it increases the SOC in the lower layer. Carbon could be retained in deeper layers for longer periods than the $\mathrm{C}$ in the soil surface. Zero tillage resulted in more water being retained in the upper $5 \mathrm{~cm}$ of the soil profile.

\subsection{Carbon stocks in different land-use systems in hillside conditions in Mexico (Etchevers, 2002; Martínez, 2002)}

An example of carbon content in the above-ground, root and soil components under different land-use systems are presented in Table III (Etchevers, 2002).

The highest $\mathrm{C}$ stock (above - ground + roots + soil) was found in the Mixe watershed (306 $\mathrm{Mg} \mathrm{ha}^{-1}$ ) and the lowest in the Cuicateca $\left(84 \mathrm{Mg} \mathrm{ha}^{-1}\right)$. However, $\mathrm{C}$ stocks associated with different land uses (secondary native forest, permanent agricultural crops, and annual and mixed annual + fruit trees crops) did not differ much within the watersheds. The hypothesis that under hillside conditions the agricultural systems accumulate as much $\mathrm{C}$ as secondary native forest systems was confirmed.
Table IV. C capture by residual weeds and stubble measured after harvesting the maize and $\mathrm{C}$ sequestered by fruit trees in various management systems (Etchevers, 2002).

\begin{tabular}{lccccc}
\hline Plot & \multicolumn{2}{c}{ Weed C } & \multicolumn{2}{c}{ Stubble C } & Peach tree C \\
& 2001 & 2002 & 2001 & 2002 & Inc. year \\
& \multicolumn{5}{c}{ Mg ha $^{-1}$} \\
$\mathrm{Plw}^{1}$ & 1.3 & 1.6 & 4.3 & 4.3 & 1.9 \\
$\mathrm{CT}^{1}$ & 0.6 & 1.3 & 3.2 & 3.2 & \\
$\mathrm{TT}^{1}$ & 1.0 & 1.1 & 3.3 & 1.9 & \\
$\mathrm{Plw}^{2}$ & 1.6 & 2.1 & 2.3 & 2.3 & 0.9 \\
$\mathrm{CT}^{2}$ & 1.2 & 2.5 & 2.2 & 2.2 & \\
$\mathrm{TT}^{2}$ & 1.4 & 1.4 & 1.8 & 1.9 & \\
& & & & \\
$\mathrm{Clw}^{2}$ & 0.9 & 2.4 & 2.8 & 2.8 & 1.3 \\
$\mathrm{CT}$ & 1.0 & 1.6 & 3.4 & 3.4 & \\
$\mathrm{TT}$ & 0.7 & 1.9 & 2.9 & 2.9 & \\
\hline
\end{tabular}

$\mathrm{Plw}=$ Peach living walls; $\mathrm{Clw}=$ Coffee living walls $; \mathrm{CT}$ and TT $=\mathrm{Con}-$ servation tillage and Traditional tillage; ${ }^{1}>30 ;{ }^{2}<30=$ slope percentage. 
Table V. Soil C losses in surface runoff in a Mazateca Watershed (Martínez, 2002).

\begin{tabular}{|c|c|c|c|c|c|}
\hline \multirow[t]{2}{*}{ Land use $^{1}$} & \multirow{2}{*}{$\begin{array}{c}\text { Rainfall } \\
\mathrm{mm}\end{array}$} & \multirow{2}{*}{$\begin{array}{c}\text { Runoff } \\
\text { L }\end{array}$} & \multirow{2}{*}{$\begin{array}{l}\text { Erosion } \\
\mathrm{kg} \mathrm{ha}^{-1}\end{array}$} & \multicolumn{2}{|c|}{$\mathrm{C}(\mathrm{ppm})^{2}$} \\
\hline & & & & Soil & Water \\
\hline Coffee & 2215 & 305 & 2.4 & 20 & 67 \\
\hline Maize- Traditional (L) & 2282 & 373 & 2.3 & 11 & 12 \\
\hline Maize + peach intercrop. (L) & 2245 & 162 & 1.5 & 27 & 5 \\
\hline Slash-and-Burn & 2353 & 446 & 6.3 & 15 & 6 \\
\hline Pasture & 2349 & 1878 & 88.7 & 11 & 4 \\
\hline "Acahual" & 2365 & 244 & 1.4 & 39 & 9 \\
\hline Maize- Traditional (H) & 2020 & 618 & 11.5 & 12 & 10 \\
\hline Maize + peach intercrop. $(\mathrm{H})$ & 2024 & 205 & 1.1 & 14 & 4 \\
\hline
\end{tabular}

${ }_{1}^{1} \mathrm{H}$ and $\mathrm{L}$ refers to high and low locations within the watershed.

${ }^{2}$ Values are too small to be expressed in $\mathrm{kg} \mathrm{ha}^{-1}$.

In a similar manner, it was observed that $\mathrm{C}$ stored in the underground portion of the systems was higher than that stored in the above-ground one. In general, more than $90 \%$ of the $\mathrm{C}$ was stored in the soil in the agricultural systems and less than $90 \%$ in the secondary native forestry.

A trend to store a major proportion of the $\mathrm{C}$ in the aboveground portion of the system was observed as the secondary forestry vegetation grew older. The annual increment of $\mathrm{C}$ in the system including fruit trees was approximately 1 to $2 \mathrm{Mg} \mathrm{ha}^{-1} \mathrm{y}^{-1}$. C stocked in the soil depends more on the quality of residues and moisture conditions than on the age of the system. The analysis of the vertical distribution of $C$ underground showed that $\mathrm{C}$ percentage diminished with depth. Approximately $60 \%$ of $\mathrm{C}$ was concentrated in the first $50 \mathrm{~cm}$ of the soil profile (Acosta et al., 2001, 2002); however, a great spatial variability of the $\mathrm{C}$ was observed within small distances in both the experimental and observation plots (Vergara et al., 2002).

Table IV shows the amount of $\mathrm{C}$ that can be captured in weeds, stubble, and peach and coffee trees of living walls and barrier systems (PLW <30), conservation tillage (CT) and traditional tillage (TT), in the two experimental micro-watersheds (Mazateca and Mixe). Weeds can introduce between 1 and $2.5 \mathrm{Mg} \mathrm{ha}^{-1} \mathrm{y}^{-1}$ of $\mathrm{C}$ to the system, while $\mathrm{C}$ in crop residues may add between 2 and $4 \mathrm{Mg} \mathrm{ha}^{-1} \mathrm{y}^{-1}$ of $\mathrm{C}$. Part of this $\mathrm{C}$ is rapidly mineralized but some remains in the soil contributing to the soil $\mathrm{C}$ pools. High density peach tree plantations used as living walls to prevent erosion in hillside conditions can sequester between 1 and $2 \mathrm{Mg} \mathrm{ha}^{-1} \mathrm{y}^{-1}$ of $\mathrm{C}$ during the first years after planting. This rate of $\mathrm{C}$ sequestration is considered comparable to rates exhibited by forestry systems (Galinski and Küppers., 1994).

Total $\mathrm{C}$ and dissolved-C losses due to erosion under hillside conditions in a micro-watershed of the Northern Sierra of Oaxaca are presented as an example in Table V (Martínez, 2002). $\mathrm{C}$ lost in the soil sediments and in the water runoff was rather small in spite of the high slopes (ranging from 20 to 60\%) and the rainfall (between 2000 and $2200 \mathrm{~mm}$ ). Soil water infiltration was very high.

The $\mathrm{C}$ in the soil sediments and water runoff plots was very small in spite of the high slopes. The insignificance of the $\mathrm{C}$ lost can be explained by the low rate of erosion and high rate of water infiltration. Traditional land use such as slash-andburn may not be as aggressive to soil $\mathrm{C}$ as is generally considered.

\subsection{Carbon accumulation in recovered hardened volcanic materials (“Tepetates") (Báez et al., 2002)}

Báez (2001) presents information on the evolution of C concentration in hardened volcanic material (tepetates) after their physical and chemical properties were ameliorated (Fig. 1). The $\mathrm{C}$ content of the original material is close to nil. Accumulated $\mathrm{C}$ (sequestered) is a clear function of management and time. Large extensions of these materials could be habilitated and subjected to conservation practices to capture atmospheric carbon in Mexico.

\subsection{Management effects on soil carbon accumulation (Salinas et al., 2001; Velázquez et al., 2001)}

Salinas et al. (2001) and Velázquez and Pérez (2001) observed that zero tillage and preserving the crop residues in the surface resulted in more organic $\mathrm{C}$ accumulation in the top soil. The work of these authors was conducted in volcanic soils in the state of Michoacán. Zero tillage in both cases resulted in a good alternative to increase $\mathrm{C}$ sequestration by soils.

\section{Organic Carbon, \%}

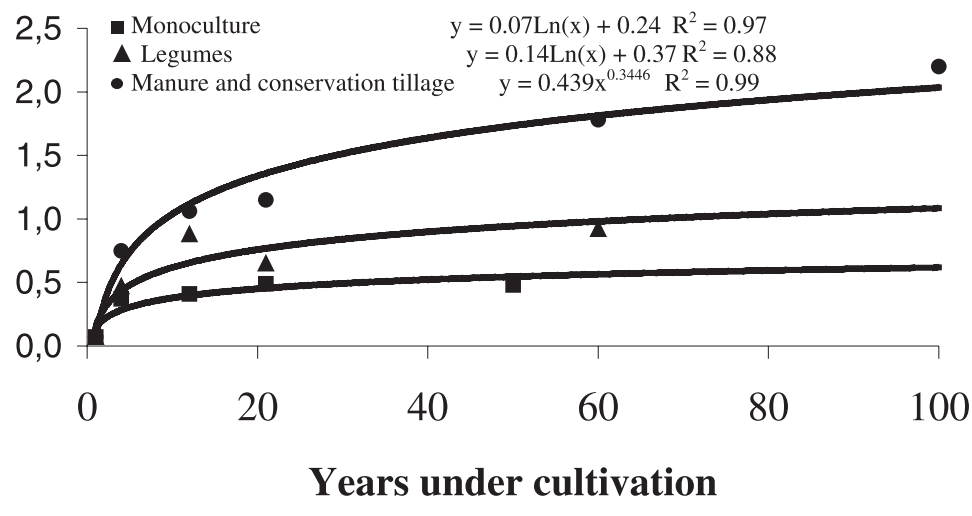

Figure 1. Organic $\mathrm{C}$ accumulation under different management systems in indurate volcanic material ("tepetate") conditioned for agriculture (Baez et al., 2002). 


\section{SOIL EROSION}

Most information on soil erosion losses has been obtained from measurements conducted in small runoff plots. However, large watersheds and models have also been studied. Variables studied on the small plots range from crops to soil management systems. Plots have been installed in dryland regions as well as on irrigated areas. Three contrasting conditions have been selected in the present paper: dryland agriculture, volcanic soils and hillside.

\subsection{Soil erosion under rainfed-semiarid conditions. The Aguascalientes study case (Osuna, 1997)}

Table VI shows the soil lost under various crops in a region with marked differences in seasonal precipitation (Osuna, 1997). Average rainfall was $587 \mathrm{~mm} \mathrm{y}^{-1}$ and had high erosive potential. Maize and beans are crops that require frequent weeding and showed higher soil losses than wheat, a crop that protects the surface because of its higher plant population. The effect of soil losses when maize was managed under different management practices is shown in Table VII. Under certain very specific conditions soil losses can be reduced by the use of the appropriate type of plow and zero tillage was not the best option. Maintaining an adequate soil cover appears to be as important as not cultivating the soil. In another series of experiments conducted under similar conditions of restricted rainfall, no advantages of the zero tillage over conventional tillage were observed (Jasso, 1997). These results mean that conservation tillage is not always an appropriate technique recommended for C sequestration.

\subsection{Soil erosion in volcanic landscapes. The Pátzcuaro Basin study case (Tiscareño et al., 2000)}

Andisols are easily erodible soils under dry or wet conditions due to their poor structure. In Pátzcuaro, where the small landholders grow annual crops under steep-slope conditions, soil erosion and nutrient losses are common features. Conservation tillage seems to be an appropriate technology to solve the above-mentioned problems. Tiscareño et al. (2000) (Fig. 8).

Cropping systems, which use plow and disk on an $8 \%$ slope, produced high erosion. Soil losses averaged 3.2 $\mathrm{Mg} \mathrm{ha}^{-1} \mathrm{y}^{-1}$ in conventional tillage and approximately $0.3 \mathrm{Mg} \mathrm{ha}^{-1} \mathrm{y}^{-1}$ in no-till plots. Reduction of storm water runoff $(76 \%)$ with

Table VI. Soil losses under different crops in a rainfed region. A 4-year-period average (El Llano, Aguascalientes, Mexico) (Osuna, 1997).

\begin{tabular}{lcc}
\hline Crop & $\begin{array}{c}\text { Soil loss } \\
\mathrm{Mg} \mathrm{ha}^{-1}\end{array}$ & Relative loss \\
\hline Maize & 12.7 & 0.39 \\
Beans & 8.9 & 0.28 \\
Wheat & 1.5 & 0.05 \\
Screen & 203 & 0.07 \\
Check (permanent fallow) & 32.3 & \\
\hline
\end{tabular}

Table VII. Soil lost under different maize management systems in a rainfed region. A 4-year-period average (El Llano, Aguascalientes, Mexico) (Osuna, 1997).

\begin{tabular}{lccc}
\hline Soil management & $\begin{array}{c}\text { Soil loss } \\
\mathrm{Mg} \mathrm{ha}^{-1}\end{array}$ & $\begin{array}{c}\mathrm{C} \\
\text { coefficient }\end{array}$ & $\begin{array}{c}\text { Maize yield } \\
\mathrm{Mg} \mathrm{ha}^{-1}\end{array}$ \\
\hline Disc plow, no weeding & 5.0 & 0.08 & 1.70 \\
Grade, no weeding & 64.9 & 0.93 & 1.41 \\
Chisel, no weeding & 33.1 & 0.55 & 1.63 \\
Zero tillage & 26.3 & 0.44 & 1.10 \\
\hline
\end{tabular}

mulched no-till systems becomes a key factor to reduce sediments and promote infiltration and deep-water percolation. Soil moisture retention was also higher $(53 \%$ in the first $150-\mathrm{mm}$ soil layer) under the latter conditions. Carbon sequestration should be encouraged by conditions created in no-till treatments.

\subsection{Soil erosion in hillside slopes. The PMSL (Oaxaca) study case (Martínez, 2002)}

How soil management affects the water runoff, soil erosion and $\mathrm{C}$ losses was studied in three experimental watersheds of Oaxaca (Martínez, 2002). Table VIII shows an example of the annual runoff, soil erosion and related parameters corresponding to various soil management systems in one of the experimental watersheds.

Runoff in most conditions was very low in spite of the high precipitation recorded (1000-2000 $\mathrm{mm}$ ) and slopes ranging from 20 to nearly $50 \%$. The values of the runoff coefficient (the relation between rainfall and runoff) allows us to conclude that most of the water infiltrates and does not run off. The treatments with the lowest runoff were the maize and fruit tree intercropping. Sediment concentration in runoff was very low as well as soil erosion, notwithstanding the slope conditions and the management systems. Storage $C$ losses under these conditions were extremely low.

\section{CONSERVATION TILLAGE}

Zero tillage farming is a pre-hispanic practice probably dating back to 5000 to 9000 years ago. Seeds were planted after slashing and burning the native vegetation and the periods in between slash-and-burn cycles were long enough to allow the secondary vegetation to grow back to near its original state (Figueroa and Morales, 1992). Soil erosion was rather negligible during that period. Today farmers make an average of 10 passes of machines over their fields in the traditional mechanized system (Anonymous, 2002). FIRA (2000) estimates that in the year 2000 there were 850 thousand hectares under conservation tillage in Mexico, i.e. approximately $4 \%$ of the cultivated surface, mostly in the central states of Michoacán, Jalisco and Guanajuato. This surface is small when compared with figures given for other Latin American countries. Our interest in this subject is due to its close relationship with $\mathrm{C}$ sequestration and sustainable agriculture (Pieri, 2001; Pieri et al., 2002a, b). 
Table VIII. Water runoff, runoff coefficient and soil erosion in the Mazateca Watershed (Martínez, 2002).

\begin{tabular}{|c|c|c|c|c|c|c|}
\hline Treatment & $\begin{array}{c}\text { Rainfall } \\
\mathrm{mm}\end{array}$ & $\begin{array}{c}\text { Runoff } \\
\text { L }\end{array}$ & $\begin{array}{c}\text { Runoff } \\
\text { coeff. }\end{array}$ & $\begin{array}{l}\text { Conc } \\
\mathrm{g} \mathrm{L}^{-1}\end{array}$ & $\begin{array}{l}\text { Erosion } \\
\mathrm{g} \mathrm{lote}^{-1}\end{array}$ & $\begin{array}{l}\text { Erosion } \\
\mathrm{kg} \mathrm{ha}^{-1}\end{array}$ \\
\hline Coffee & 2215 & $305(6.1)^{1}$ & 0.0028 & 0.0392 & 12 & 2.4 \\
\hline Maize - Traditional (L) & 2282 & $373(7.5)$ & 0.0033 & 0.0301 & 11 & 2.3 \\
\hline Maize + peach intercrop. (L) & 2245 & $162(3.3)$ & 0.0014 & 0.0446 & 7 & 1.5 \\
\hline Slash-and-Burn & 2353 & $446(8.9)$ & 0.0038 & 0.0700 & 31 & 6.3 \\
\hline Pasture & 2349 & $1878(37.6)$ & 0.0160 & 0.2261 & 443 & 88.7 \\
\hline "Acahual" & 2365 & $244(4.9)$ & 0.0021 & 0.0282 & 7 & 1.4 \\
\hline Maize - Traditional $(\mathrm{H})$ & 2020 & $618(12.1)$ & 0.0061 & 0.0931 & 57 & 11.5 \\
\hline Maize + peach intercrop. $(\mathrm{H})$ & 2024 & $205(4.10)$ & 0.0020 & 0.0279 & 6 & 1.1 \\
\hline
\end{tabular}

$2.4 \mathrm{H}$ and $\mathrm{L}$ refers to high and low locations within the watershed.

1 ( ) Runoff values in $\mathrm{mm}$.

To cope with the intensive rate of degradation, conservation tillage practices have been conducted in Mexico (Claverán, 2000; Claverán and Rulfo, 2001; Claverán et al., 1997; INIFAP, 2000; RELACO, 1997; Velásquez et al., 1997), as well as in other Latin American countries (RELACO, 1993, 1995, 1997 and 1999). CIMMYT has been one of the most active institutions in conducting research on conservation tillage in Mexico and Central America (Buckles and Erenstein, 1996; Erenstein, 1997, 1999a, b; Erenstein and Cadena, 1997; Sayre, 2000; Sayre et al., 2001; Scopel, 1997a, b; Scopel and Chávez, 1997; Scopel et al., 2001; Soule, 1997; van Nieuwkoop et al., 1994); however, little reference is made to C sequestration and soil erosion losses. A similar situation occurs in this work conducted at the Colegio de Postgraduados (García, 1994; Muñoz, 1993; Magallanes, 1999; Navarro, 1998; Pérez, 1996; Román, 1993; Uribe, 1997; Sandoval, 1997; Tapia, 1999; Vidal, 1994). Experimental results have shown the significant advantages of zero tillage over both conventional and minimum tillage. Over 100 experiments conducted during a 5-year period showed that zero tillage reduced the erosion rate by nearly $80 \%$ in maize crops, and by nearly $95 \%$ in wheat crops with respect to conventional tillage (Osuna, 1997; Velásquez et al., 1997). Under moderate slope conditions (8\%) there was a considerable reduction of soil erosion in Andosols with zero tillage (90 to $60 \%$ reduction) as compared with conventional tillage (Tiscareño et al., 1997). In cultivated lands on steeper slopes in southern Veracruz, Uribe (1998) determined that $27 \mathrm{~kg}$ of soil were lost per each kilogram of maize produced under conventional tillage; under zero tillage the loss was reduced to less than $1 \mathrm{~kg}$.

\section{REFERENCES}

Acosta M., Etchevers J.D., Monreal C., Quednow K., Hidalgo C. (2001) Un método para la medición del Co en los compartimientos subterráneos (raíces y suelo) de sistemas forestales y agrícolas en terrenos de ladera en México, in: Memoria del Simposio Internacional sobre "Medición de la Captura de Carbono en Ecosistemas Forestales, Nov. 2001, Univ. Austral de Chile, Valdivia, Chile (CD ROM).

Acosta M., Etchevers J.D. (2002) Distribución de carbono orgánico en el perfil del suelo, en diferentes sistemas de bosques de la Sierra
Norte de Oaxaca, in: Congreso Nacional de la Ciencia del Suelo. Sociedad Mexicana de la Ciencia del Suelo, Torreón, Coahuila, México (CD-ROM).

Amante O.A. (1989) Variabilidad espacial y temporal de la erosión hídrica, Estudio de caso, Tesis de Maestría en Ciencia, Colegio de Postgraduados, Montecillo, México, 150 p.

Anonymous (2002) Connserving crop land, AgJournal.com September 8,2002 (http://www.agjournal.com)

Báez P.A. (2001) Dinámica del carbono orgánico en tepetates cultivados, Tesís de Maestría, Colegio de Postgraduados, Cent. Edafología, Montecillo, México.

Báez P.A., Etchevers B.J.D., Hidalgo M.C., Prat C., Ordaz C.V., Núñez E.R. (2002) Organic C and Olsen-P in cultivated tepetates of México, Agrociencia 36, 643-653.

Bocco G., García-Oliva F. (1992) Researching Gully erosion in México, J. Soil Water Conserv. 47, 365-367.

Buckles D., Erenstein O. (1996) Intensificación de los sistemas de cultivos basados en el maíz en la sierra de Santa Martha, Veracruz, NRG 96-07 Es. México, D.F.: CIMMYT, 62 p.

Claverán A.R. (2000) Conservation tillage in Mexico and Latin America: An overview, in: Mem. Simp. Intern. de Labranza de Conservación, 24 al 27 de Enero 2000, Sinaloa, México, (CDROM).

Claverán A.R., Rulfo V.F.O. (2001) Avances de Investigación en labranza de conservación II, Libro Técnico No. 2, INIFAPCENAPROS, Michoacán, México, 293 p.

Claverán A.R., Velásquez G.J., Muñoz V.J.A., Tiscareño L.M., Salinas G.J.R., Nájera R.M.B. (1997) Avances de Investigación en labranza de conservación I. Libro Técnico No. 1, INIFAP-CENAPROS, Michoacán, México, 288 p.

CONAZA (Comisión Nacional de Zonas Áridas) (1994) Plan de acción para combatir la desertificación en México, Com. Zonas Áridas, Secr. de Desarrollo Social, México, D.F., 160 p.

Erenstein O. (1997) La economía de la labranza de conservación en México, in: Claverán A.R. et al., Avances de Investigación en labranza de conservación I. Libro Técnico No. 1, INIFAP-CENAPROS, Michoacán, México, pp. 225-244.

Erenstein O. (1999a) La conservación de residuos en los sistemas de producción de maíz en Cuidad Guzmán y San Gabriel, Jalisco, Document del NEG 99-01, CIMMYT, Mexico, D.F.

Erenstein O. (1999b) The economics of soil conservation in developing countries, The case of crop residue mulching, Thesis, Wageningen University, $301 \mathrm{p}$. 
Erenstein O., Cadena P.I. (1997) La adopción de labranza de conservación en un sistema de cultivo en ladera en Motozintla, Chiapas, NRG 97-01, Es. Mexico, D.F.: CIMMYT, 54 p.

Etchevers B.J.D. (2002) Metodología para la medición de la captura de carbono, Proyecto Manejo Sostenible de Laderas, Cuarta reunión del Comité Técnico de Coordinación y Seguimiento, Colegio de Postgraduados, Montecillo, México (CD-ROM).

Etchevers B.J.D., Acosta M., Monreal C., Quednow K., Jiménez L. (2001) Los stocks de carbono en diferentes compartimentos de la parte aérea y subterránea, en sistemas forestales y agrícolas de ladera en México, Mem. del Simp. Interna. "Medición de la Captura de Carbono en Ecosistemas Forestales", Nov. 2001, Univ. Austral de Chile, Valdivia, Chile (CD ROM).

Figueroa S.B., Ventura E.R. (1990) Proyecto para el efecto de la labranza en la estructura del suelo y su relación con el crecimiento, desarrollo y rendimiento de los cultivos, Serie Doc. Téc. de la Red de Conservación de Suelo y Agua, INIFAP-SARH, Salinas, San Luis Potosí, México, 62 p.

Figueroa S.B., Morales F. (1992) Manual de producción de cultivos con labranza de conservación, Colegio de Postgraduados, Secr. de Agri. y Rec. Hidráulicos, Montecillo, México.

FIRA (2000) Informe de actividades 2000, FIRA, Morelia, Mexico, (http://www.fira.gob.mx/Informe2000/Informe2000.pdf).

Galinski W., Küppers M. (1994) Polish Forest Ecosystems: The influence of changes in the economic system on the carbon balance, Climatic Change 28, 103-119.

García S.R. (1994) Las propiedades físicas y químicas de un regosol del estado de Puebla, bajo labranza mínima y convencional, Tesis de Maestría, Col. de Postgraduados, Cent. de Edafología, México.

INEGI (1998) Estadísticas del medio ambiente, México, 1997, INEGI, SEMARNAP, $461 \mathrm{p}$.

INIFAP (2000) Simposium Internacional de Labranza de Conservación, Sinaloa, México 24 al 27 de Enero de 2000, INIFAP-CENAPROS, Michoacán, México (CD-ROM).

Jasso Ch.C. (1997) Efecto de la labranza en al estructura del suelo y su relación con el rendimiento de los cultivos, in: Claverán A.R. et al., Avances de Investigación en labranza de conservación I. Libro Técnico No. 1, INIFAP-CENAPROS, Michoacán, México, pp. $215-223$.

Kern J.S., Johnson M.G. (1993) Conservation tillage impacts on national and atmospheric carbon levels, Soils Sci. Soc. Am. J. 57, 200-210.

Lal R. (1984) Soil erosion from tropical arable lands and its control, Adv. Agron. 37, 187-242.

Lal R. (1989) Conservation tillage for sustainable agriculture: tropics vs. temperate environments, in: Lal R., Kimble J., Levine E., Stewart B. (Eds.), Soil management and greenhouse effect, Lewis Publ., Boca Raton, Florida, pp. 1-8.

Maass J.M.M., García-Oliva F. (1990) La conservación de suelos en zonas tropicales: el caso de México, Ciencia Desarrollo 90, 21-36.

Magallanes E.A. (1999) Efecto de la estabilidad de agregados y la labranza en el rendimiento y acumulación de nitratos en el sistema suelo, planta, Tesis de Doctorado, Colegio de Postgraduados, Inst. de Rec. Nat., Especialidad de Edafología, Montecillo, México.

Martínez M.M. (2002) Caracterización geográfica y medición de escurrimientos, Proyecto Manejo Sostenible de Laderas, Cuarta reunión del Comité Técnico de Coordinación y Seguimiento, Colegio de Postgraduados, Montecillo, México (CD-ROM).

Muñoz R.J. de J. (1993) Efecto de la labranza y residuos de cosecha sobre las propiedades físicas del suelo y su influencia en la producción de maíz bajo condiciones de temporal en Durango, Tesis de Maestría, Colegio de Postgraduados, Cent. de Edafología, México.
Navarro B.A. (1998) Sistema de labranza en la preparación de camas de siembra para la emergencia y desarrollo inicial del maíz y fríjol, Tesis de Doctorado, Colegio de Postgraduados, Inst. de Rec. Nat., Especialidad de Edafología, Montecillo, México.

Osuna C.E.S. (1991) Efecto de la cobertura vegetal en el proceso erosivo, Mem. Sem. "Conservación de Agua y Suelo (Manejo integral de cuencas)", SARH-CNA-IMTA, México, D.F., pp. 148-166.

Osuna C.E.S. (1997) Investigación sobre erosión y labranza de conservación en al región Norte-Centro de México, in: Claverán A.R. et al., Avances de Investigación en labranza de conservación I. Libro Técnico No. 1, INIFAP-CENAPROS, Michoacán, México, pp. 199-214.

Pérez N.J. (1996) Efectos de la erosión y sistemas de labranza sobre la productividad y rentabilidad de dos suelos de Oaxaca, Tesis de Doctorado, Colegio de Postgraduados, Inst. de Rec. Nat., México.

Pieri C. (2001) Strategies for international cooperation, in: I World Congress on Conservation Agriculture, Madrid, España, 1-5 October, 2001, ECAF, Madrid, España.

Pieri C., Evers G., Landers J., O'Connell P., Terry E. (2002a) A road map from conventional to No-Till Farming, The International Bank for Reconstruction and Development, Washington, D.C., 20 p.

Pieri C., Evers G., Landers J., O'Connell P., Terry E. (2002b) No-till farming for sustainable development. The International Bank for Reconstruction and Development, Washington, D.C., 65 p.

RELACO (Red Latinoamericana de Labranza de Labranza Conservacionista) (1993) Memoria I Reunión Bienal la Red Latinoamericana de Labranza de Conservación, Pla Sentís I., Ovalles F. (Eds.), Maracay, Venezuela, $386 \mathrm{p}$.

RELACO (Red Latinoamericana de Labranza de Labranza Conservacionista) (1995) Memoria IV Reunión Bienal de la Red Latinoamericana de Labranza de Conservación, Bertsch F., Monreal C. (Eds.), San José, Costa Rica.

RELACO (Red Latinoamericana de Labranza de Labranza Conservacionista) (1997) Memoria IV Reunión Bienal Red Latinoamericana de Agricultura de Conservacionista, Claverán A.R., Rulfo V.F.O. (Eds.), Morelia, Michoacán, México, 361 p.

RELACO (Red Latinoamericana de Labranza de Labranza Conservacionista) (1999) Memoria V Reunión Bienal Red Latinoamericana de Agricultura de Conservacionista, Brasil, (CD-ROM).

Román C.S.S. (1993) Respuesta agronómica y dinámica del nitrógeno del suelo en trigo, maíz, veza y medicago, bajo distintos manejos de la labranza, residuos de cosecha y fertilización nitrogenada, Tesis de Maestría, Colegio de Postgraduados, Cent. de Edafología, México.

Salinas G., Gallardo V.J.R.M., Caballero H.F. (2001) Efecto de al labarnza de conservación en la distribución de carbono y nutrimentos, in: Claverán A.R., Rulfo V.F.O. (Eds.), Avances de Investigación en Agricultura Sotenible II, CENAPROS-INIFAP, Morelia, Micoacán, México.

Sandoval E.M.A. (1997) Indicadores de calidad de suelos con diversos manejos, Tesis de Maestría, Colegio de Postgraduados, Inst. de Rec. Nat., Especialidad de Edafología, Montecillo, México.

Sayre K.D. (2000) Effects of tillage, crop residue retention and nitrogen management on the performance of bed-planted, furrow irrigated spring wheat in northern Mexico, in: 15th Conference of the International Soil Tillage Research, July 2-7, Forth Worth, Texas.

Sayre K.D., Mezzalama M., Martínez M. (2001) Tillage, crop rotation and crop residue management effects on maize and wheat production for rainfed conditions in the altiplano of central Mexico, in: I World Congrees on Conservation Agriculture, October 1-5, Madrid, Spain.

Scopel E. (1997a) Labranza de conservación para maíz de temporal, in: Claverán A.R. et al., Avances de Investigación en labranza de conservación I. Libro Técnico No. 1, INIFAP-CENAPROS, Michoacán, México, pp. 77-90. 
Scopel E. (Ed.) (1997b) Memoria del taller de transferencia de labranza de conservación para maíz de temporal en el Estado de Jalisco, México, D.F.: CIMMYT, INIFAP, CIRAD, SDR, 83 p.

Scopel E., Chávez G.E. (1997) Efectos de la labranza de conservación sobre el balance hídrico del cultivo del maíz de temporal, in: Claverán A.R. et al., Avances de Investigación en labranza de conservación I. Libro Técnico No. 1, INIFAP-CENAPROS, Michoacán, México, pp. 91-106.

Scopel E., Tardieu F., Edmeades G.O., Sebillote M. (2001) Effects of conservation tillage on water supply and rainfed maize production in semiarid zones of West-Central Mexico, NRG Paper 01-01, CIMMYT, Mexico, D.F.

SEMARNAP (1997) Secretaría de Medio Ambiente y Recursos Naturales, Web page: http://www.semarnap.gob.mx (24 de enero de 2003).

Soule M.J. (1997) Farmer assessment of velvetbean as a green manure in Veracruz, Mexico: Experimentation and expected profits, NRG paper 97-02, Mexico, D.F.: CIMMYT, 21 p.

Tapia V.L.M. (1999) Escurrimientos y producción de sedimentos en sistemas de manejo agrícola en la cuenca del Lago de Pátzcuaro, Tesis de Doctorado, Colegio de Postgraduados, Inst. de Rec. Nat., Especialidad de Edafología, Montecillo, México.

Tiscareño M., Gallardo M., Velásquez M. (1997) Impacto de los sistemas de labranza en la agricultura de ladera, in: Claverán A.R., Velásquez G.J., Muñoz V.J.A., Tiscareño L.M., Salinas G.J.R., Nájera R.M.B. (Eds.), Avances de Investigación en labranza de conservación I. Libro Técnico No. 1, INIFAP-CENAPROS, Michoacán, México, 288 p.

Tiscareño-López M., Báez-González A.D., Velázquez-Valle M., Claverán-Alonso R., Potter K.N., Stone J.J. (2000) Case Study: Conservation Tillage to Save Patzcuaro Lake Watershed, in: Mem.
Simp. Inter. de Labranza de Conservación, 24-27 Jan. 2000, Sinaloa, México (CD-ROM).

Uribe G.S. (1997) Manejo pro-sustentable de laderas con terrazas de muro vivo en el trópico sub-húmedo, Tesis de Doctorado, Colegio de Postgraduados, Inst. de Rec. Nat., Especialidad de Edafología, Montecillo, México.

Uribe G.S. (1998) Tecnologías prosostenibles de manejo de suelos tropicales en el sur de Veracruz, Mem. de la XII Reunión Científica y Tecnológica, Forestal y Agropecuaria INIFAP-CIRGOC, pp. 93100.

van Nieuwkoop M., Walter W.B., Zamarripa A.M., de la Piedra R.C., Cruz F.U.C., Camas R.G., Martínez J.L. (1994) La adopción de tecnologías de labranza de conservación. La Fraylesca, Chiapas, CIMMYT-INIFAP, $93 \mathrm{p}$

Velásquez G., Pérez J.P. (2001) Interacción labranza-fertilizaciónresiduos en maíz de temporal en la región centro de México, in: Claverán R., Rulfo V.F.O. (2001) Avances de Investigación en labranza de conservación II. Libro Técnico No. 2, INIFAPCENAPROS, Michoacán, México, 293 p.

Velásquez V.M., Tiscareño M., Claverán R., Gallardo M. (1997) Erosión y productividad bajo labranza de conservación I. Avances de investigación en suelos de ando de Michoacán, INIFAPCENAPROS, Folleto Técnico No. 1, 34 p.

Vergara M.A., Etchevers B.J.D., Vargas H.M. (2002) Variabilidad del carbono orgánico en suelos de ladera del sureste de México, Agrociencia (to be published).

Vidal P.I.R. (1994) Estimación in situ de la mineralización de nitrógeno en trigo bajo diversas rotaciones y sistemas de labranza, Tesis de Doctorado, Colegio de Postgraduados, Cent. Edafología, México.

WRI-World Resource Institute (2002) World resources 1998-1999, Regions at glance, Central America, (http://www.wri.org, August, 2002). 